\title{
ARTICLE
}

\section{The evaluation of environmental and socio-cultural impacts of tourism on the Khorgo-Terkhyn Tsagaan Nuur National Park}

Khishigdalai Ulaankhuu*

School of Business, University of the Humanities, Ulaanbaatar, Mongolia

Abstract: The Khorgo-Terkhiin Tsagaan Nuur National Park is one of the major tourist destinations in Mongolia. The Park, in recent years, has witnessed a significant increase in the number of visiting local tourists. The present research was conducted to assess the environmental, social and cultural impacts of tourism in the region particularly today when we talk about sustainable tourism. To assess these impacts, as assessment method was used which is applied internationally. These impacts were based on three criterion for sustainable development-environmental impacts, social and cultural impacts. The National Park has been facing environmental impacts such as poor waste management, soil erosion, overgrazing, and water pollution. Even though it has some great impacts on the social, cultural and environmental aspects and its products and services, preserving traditional and cultural heritages and improving the skills of local and tourist workers, it continues to have a negative affect on the traditional customs, national arts and culture. Therefore, it is important that the means and methods of reducing these negative impacts should be planned and developed in the near future.

Keywords: Khorgo-Terkhyn Tsagaan Nuur National Park; environmental impact; socio-cultural impact and sustainable development;

\section{INTRODUCTION}

In recent years, the concept of developing sustainable tourism-management has been adopted internationally to improve Protected Areas (PA) [1].

Most of the international tourists visiting Mongolia travel to PAs and deliberately eight out of every ten tourists have traveled to PA [2].

The International Union for Conservation of Nature (IUCN) has noted that the implementation of sustainable tourism management in the Pas [3] has a positive impact on the environment, socio-culture and the economy. The Khorgo-Terkh Tsagaan Nuur National Park (KTTNNP) is located in the central part of the Khangai Mountains and has a unique volcanic lake with humid weather conditions. The National Park was included in the list of the Ramsar Convention of Wetland Protection in 1997 [4].

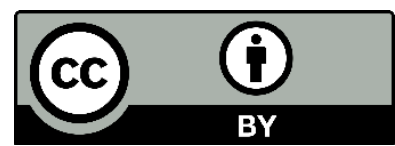

The Author(s). 2020 Open access This article is distributed under the terms of the Creative Commons Attribution 4.0 International License (https://creativecommons.org/licenses/by/4.0/), which permits unrestricted use, distribution, and reproduction in any medium, provided you give appropriate credit to the original author(s) and the source, provide a link to the Creative Commons license, and indicate if changes were made. 
It is impending to study the ecosystem of the region, protect and develop sustainable tourism in order to increase the economic value.

Accordingly, the survey was conducted to identify the level of environmental and socio- cultural impacts of tourism on the National Park.

The purpose of the study is to assess the environmental and socio-cultural impacts of tourism on the National Park and to determine the basis for sustainable tourism development.

\section{MATERIALS AND METHODS}

\section{The current condition of the tourism in the Khorgo-Terkhyn Tsagaan Nuur National Park}

KTTNNP is one of the fastest-growing PAs in Mongolia in terms of tourism. The number of tourists visiting the National Park is shown in table 1.

Table 1. Number of visitors visiting the National Park

\begin{tabular}{|c|c|c|c|}
\hline \multirow{2}{*}{ Year } & \multicolumn{2}{|c|}{ Number of visitors (Person ) } & $\begin{array}{c}\text { Total number of visitors } \\
\text { (Person) }\end{array}$ \\
\cline { 2 - 4 } & International & Domestic & 6,958 \\
\hline 2008 & 4,188 & 2,770 & 7,196 \\
\hline 2009 & 3,922 & 3,274 & 6,409 \\
\hline 2010 & 3,486 & 2,923 & 8,340 \\
\hline 2011 & 3,601 & 4,739 & 7,121 \\
\hline 2012 & 2,151 & 4,970 & 12,471 \\
\hline 2013 & 1,829 & 10,642 & 17,489 \\
\hline 2014 & 2,926 & 14,563 & 21,714 \\
\hline 2015 & 4,291 & 17,423 & 25,854 \\
\hline 2016 & 3,354 & 22,500 & 37,764 \\
\hline 2017 & 4,764 & 33,000 & 48,012 \\
\hline
\end{tabular}

As shown in Table 1, the number of domestic visitors to KTTNNP has been increasing, which almost doubled in 2013. The number of international tourists has declined steadily from 2008, receiving the lowest number of tourists (1829) in 2013. However, the number had increased by $60 \%$ in 2014 and $47 \%$ in 2015. In 2016, the number of international tourists shrunk by $21.8 \%$ (Figure $1)$.

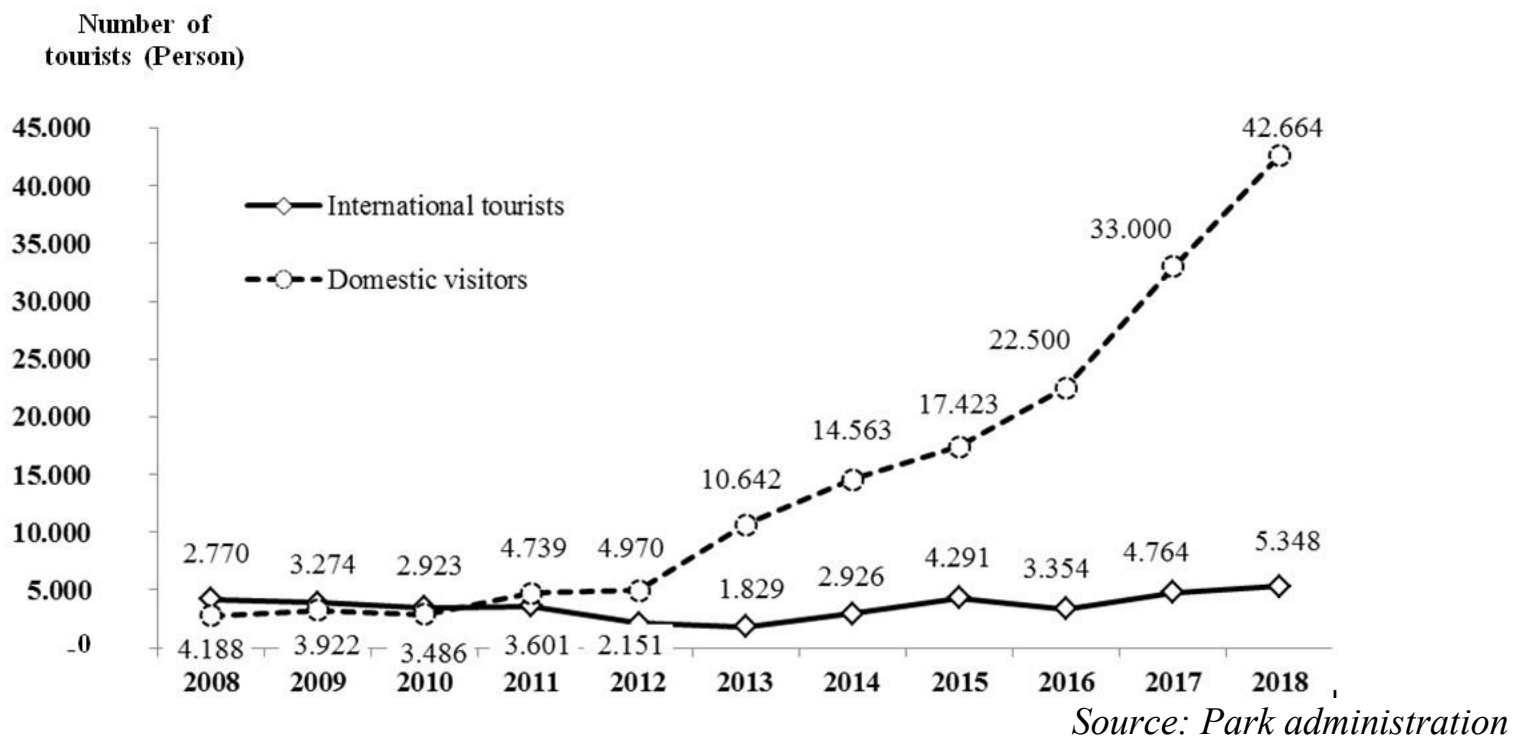

Figure 1. Number of visitors visiting the National Park 
$87 \%$ of the total visitors visiting the KTTNNP are domestic visitors, while the remaining $12.9 \%$ are international visitors. There are about 600 tour operators in Mongolia and 15 of them that are operating in the area were chosen to define the tour itinerary. The following four itineraries have been provided to the visitors [1].

Tour itinerary 1

Ulaanbaatar-Khara Khorum-TsetserlegKhorgo-Terkhiin Tsagaan Nuur-MurunKhuvsgul Lake-Murun-Ulaanbaatar.

Tour itinerary 2

Ulaanbaatar-Elsen Tasarkhai-Khara

Khorum-Tsenkheryn Hot Springs-Khorgo-

Terkhiin Tsagaan Nuur-Ugii LakeUlaanbaatar.

Tour itinerary 3

Ulaanbaatar-Umnugobi-Gobi Gurvan Saikhan-Khongoryn Els-Yolyn Am-Khara Khorum-Khorgo-Terkhiin Tsagaan Nuur-Ugii Lake-Tsenkheryn Hot Springs-Ulaanbaatar.

Tour itinerary 4

Ulaanbaatar-Amarbayasgalant-Uran

Togoo-Murun-Uushgyn Bugan ChuluuKhuvsgul Lake-Jargalant-Khorgo-Terkhiin Tsagaan Nuur-Tsenkher-Khara Khorum-OngiBayanzag-Khongoryn Els-Yolyn Am-Gun Galuut-Terelj-Ulaanbaatar.

For domestic travelers, the main itinerary of their trip is similar to the above-mentioned itineraries and they mostly travel independently with their families and friends for 2-3 days [1].

The following travel itinerary has been developed and implemented by the
Administration of the Khangai Mountain Range [1].

Itinerary: Tsetserleg-Tariat soum 170 km-Khorgo Togoo 5 km-Gants Huny Agui 3 km-Shar Nohoin Tam, Musun khongil 2 kmZaluusyn Khongil 3 km-Uvgun Khad 3 kmTerkhiin Tsagaan Nuur-Tsetserleg 186 km.

\section{The main attractions and resource evaluation}

The main attractions included in the travel programme are Khorgyn Togoo, Terkhiin Tsagaan Nuur, Gants Khuny Agui, Shar Nokhoin Tam and Uvgun Khad [4]. In addition to these natural attractions, there are many historical and cultural treasures in the National Park as well.

\section{Evaluation of the recreational condition}

An analysis of the environmental and climatic conditions of the KTTNNP shows that the average indicator is 2.5 points [1], which is considered suitable for tourism in this region.

The travel-recreation load in the Khorgyn Togoo area is $420 \mathrm{per} / \mathrm{ha}$, or 1.4 times higher than the norms of natural regeneration (300 persons per ha), in Terkhiin Tsagaan Nuur area, it is $336 \mathrm{per} / \mathrm{ha}$ or 1.12 times higher [5]. This shows that the National Park is overloaded during peak tourist season.

\section{The capacity of the accommodation}

There are 14 licensed tourist camps in the National Park and 8 of them are active [4]. The capacity of tourist accommodation operating in the National Park is shown below.

Table 2. The capacity of tourist accommodation

\begin{tabular}{|c|c|c|c|c|c|c|c|c|}
\hline & \multicolumn{2}{|c|}{ Hotel } & \multicolumn{2}{c|}{ Guesthouse } & \multicolumn{2}{c|}{ Tourist Camp } & \multicolumn{2}{c|}{ Ger Camp } \\
\cline { 2 - 8 } & Number & $\begin{array}{c}\text { Number } \\
\text { of beds }\end{array}$ & Number & $\begin{array}{c}\text { Number } \\
\text { of beds }\end{array}$ & Number & $\begin{array}{c}\text { Number } \\
\text { of beds }\end{array}$ & Number & $\begin{array}{c}\text { Number } \\
\text { of beds }\end{array}$ \\
\hline KTTNNP & 0 & 0 & 1 & $20-30$ & 8 & 445 & $\begin{array}{c}35 \\
\text { households } \\
145 \text { gers }\end{array}$ & 580 \\
\hline
\end{tabular}

Tourist camps and guesthouses are mainly located in the northern shores of the lake. In other words, the camps are established based on the main tourist attractions. On the southern shore of the lake, the "Dalai Van" tourist camp and 3 other guesthouses are located. There are 2 camping sites with 1 hectare of land each located in the Surtyn Am area. 
Services provided to tourists are shown below (Table 3 ). There are food services, and markets and souvenir shops are located in Tariat soum.

Table 3. Types and numbers of services for tourists

\begin{tabular}{|c|c|c|c|c|c|c|c|}
\hline Museum & Club & Restaurant & Market & Shop & Guide & $\begin{array}{c}\text { Souvenir } \\
\text { shop }\end{array}$ & $\begin{array}{c}\text { Guides with } \\
\text { private vehicle }\end{array}$ \\
\hline- & 1 & 15 & 15 & 5 & - & - & - \\
\hline
\end{tabular}

Methodology of evaluating the environmental, socio-cultural impacts of tourism

The International Union for Conservation of Nature (IUCN) has developed the general principles of sustainable tourism [6]. These principles aim to promote eco-tourism as well as to increase the positive impacts of tourism on the environment, society and economy.

After studying the recommendations on sustainable tourism planning by the European Union (EU) for evaluating the environmental, social and economic impacts [7], recommendations by the International Union for Conservation of Nature (IUCN) [6] and international research organizations [8], IEPA recommendations have been chosen as the general methodology. According to the "Methodology to estimate the impact of tourism on the environment, society and economy" by Gansukh. D, Erdenetuul. S and Navchaa. T, the environmental impacts are defined by 6 categories and 24 criteria and the socio-cultural impacts are determined by 2 categories and 23 criteria.

The environmental impacts from tourism have been assessed by $(-3)$ to 0 points in 24 criteria and six categories, such as soil, geology, geomorphology, water, landscape, wildlife, and plants [9].

The socio-cultural impact has been assessed by $(-1)$ to 1 point in 23 criteria and 2 categories.

The evaluation used observation methods and questionnaires. About 100 people and 16 business organizations responded to the questionnaire.

\section{RESULTS}

SWOT analysis is shown in Table 4, which was based on the current tourism conditions, attractions, and resource evaluation.

Table 4. SWOT analysis of the Khorgo-Terkhiin Tsagaan Nuur National Park

\begin{tabular}{|c|c|}
\hline Strengths & Weaknesses \\
\hline $\begin{array}{l}>\text { Relatively well-developed infrastructure } \\
\text { Attracted to the tourism market earlier } \\
>\text { The market is well-known } \\
>\text { The intersection of major tourist attractions } \\
\text { along a vertical and horizontal axis } \\
>\text { Local community participation is active } \\
>\text { Clear routes and directions } \\
>\text { Traffic signs and information boards are put }\end{array}$ & $\begin{array}{l}\text { Excessive concentration of tourists during the } \\
\text { peak season } \\
>\text { Closely located camps } \\
>\text { Increased environmental impact of domestic } \\
\text { visitors } \\
>\text { Unrestricted area for camping } \\
>\text { Quality and standard of the ger camps are poor } \\
\text { and lack of sanitation facilities } \\
>\text { Transit place for tourists } \\
>\text { Bumpy roads } \\
>\text { Lack of camping sites } \\
>\text { Lack of collaboration between tour operators } \\
\text { and local authorities }\end{array}$ \\
\hline
\end{tabular}




\section{Opportunities}

Reduce the environmental threats by establishing internal zoning and enforcing regional zones

$>$ Replan the land and upgrade the guest houses and sanitation facilities

$>$ Reduce the negative impacts of visitors with tents by adding and decorating the camping sites

$>$ Increase the income of local communities by creating new travel types for tourists

$>$ Reduce soil erosion by putting asphalt road from Tariat to Terkhiin Tsagaan Nuur
Threats

Soil erosion due to excessive concentration of tourist

Threats on the environment from domestic visitors

$>$ Environmental degradation and lake pollution due to poor sanitation facilities

$>$ Reduced tourists satisfaction and arrivals due to poor environmental condition

$>$ Lose tourists to other destinations
According to the study and survey, such environmental impacts as waste, soil erosion, land degradation, overgrazing, water pollution and improper use of land have been observed (Table 5).

Table 5. Environmental Impact Evaluation of Tourism

\begin{tabular}{|l|c|c|c|c|c|c|c|c|}
\hline \multicolumn{1}{|c|}{ Impact } & \multicolumn{9}{|c|}{ Negative impact } & \multicolumn{2}{c|}{ No impact } \\
\hline Evaluation & -3 & $\begin{array}{c}\text { By } \\
\text { percentage }\end{array}$ & -2 & $\begin{array}{c}\text { By } \\
\text { percentage }\end{array}$ & -1 & $\begin{array}{c}\text { By } \\
\text { percentage }\end{array}$ & 0 & $\begin{array}{c}\text { By } \\
\text { percentage }\end{array}$ \\
\hline Lack of freshwater & 0 & 0 & 8 & 6.8 & 11 & 9.4 & 97 & 83.6 \\
\hline Water pollution & 20 & 17.2 & 11 & 9.4 & 19 & 16.3 & 80 & 68.9 \\
\hline Waste & 34 & 29.3 & 30 & 25.8 & 19 & 16.3 & 33 & 28.4 \\
\hline $\begin{array}{l}\text { Shortage of biological } \\
\text { species }\end{array}$ & 12 & 10.3 & 8 & 6.8 & 14 & 12.1 & 82 & 70.6 \\
\hline $\begin{array}{l}\text { Soil erosion and } \\
\text { inappropriate use of } \\
\text { land }\end{array}$ & 9 & 7.8 & 19 & 16.4 & 33 & 28.5 & 55 & 47.4 \\
\hline
\end{tabular}

Note: Impacts are assessed by the survey participants and -3 indicates negatively impacted and 0 indicates no negative impacts

However, air pollution, lack of freshwater, and biodiversity loss are not affected, but water and soil pollution are likely to have an impact, which may result in the risk of biodiversity loss and shortage of freshwater.
Tourism has positive impact on the socioculture by developing the organization's foreign relations, products, types and quality of services, protecting the natural and historical attractions and improving the skills of staff of the tourism sectors. (Table 6).

Table 6. Socio-Cultural Impact Evaluation of Tourism

\begin{tabular}{|c|c|c|c|c|c|c|}
\hline Impact & \multicolumn{2}{|c|}{ Negative impact } & \multicolumn{2}{|c|}{ No impact } & \multicolumn{2}{|c|}{ Positive impact } \\
\hline Evaluation & -1 & $\begin{array}{c}\text { By } \\
\text { percentage }\end{array}$ & 0 & $\begin{array}{c}\text { By } \\
\text { percentage }\end{array}$ & 1 & $\begin{array}{c}\text { By } \\
\text { percentage }\end{array}$ \\
\hline \multicolumn{7}{|c|}{ Social characteristics } \\
\hline Organization's foreign relations & & & & & 116 & 100 \\
\hline Structure of the organization & & & 29 & 25 & 87 & 75 \\
\hline Types of products and services & & & & & 116 & 100 \\
\hline Employee's activity and productivity & & & 29 & 25 & 87 & 75 \\
\hline Employee skills & & & 29 & 25 & 87 & 75 \\
\hline
\end{tabular}




\begin{tabular}{|l|c|c|c|c|c|c|}
\hline Language skills & & & 31 & 26.8 & 85 & 73.2 \\
\hline Opportunities to have new friends & & & 29 & 25 & 87 & 75 \\
\hline Religion & & & $\begin{array}{c}11 \\
6\end{array}$ & 100 & & \\
\hline Environmental noise & & & 73 & 63 & 43 & 37 \\
\hline Leisure time & & & 87 & 75 & 29 & 25 \\
\hline Utilization of public lands & & & 44 & 38 & 72 & 62 \\
\hline Waste and pollution & 93 & 80 & 23 & 20 & & \\
\hline Business opportunities for locals & & & 51 & 44 & 65 & 56 \\
\hline Lifestyle & & & 44 & 38 & 72 & 62 \\
\hline Social life & & & 29 & 25 & 87 & 75 \\
\hline & Cultural characteristics & & & \\
\hline Traditional customs & 11 & 9.5 & 35 & 30.2 & 70 & 60.3 \\
\hline National Art and Cultural Development & 21 & 18 & 31 & 27 & 64 & 55 \\
\hline $\begin{array}{l}\text { Protection of historical and cultural } \\
\text { heritage and attraction }\end{array}$ & & & 31 & 27 & 85 & 73 \\
\hline $\begin{array}{l}\text { Protection of natural sites and } \\
\text { environment }\end{array}$ & & & 10 & 8.6 & 106 & 91.4 \\
\hline $\begin{array}{l}\text { Pride and value of the traditional culture } \\
\text { and history }\end{array}$ & & & 10 & 8.6 & 106 & 91.4 \\
\hline Service culture & & & 35 & 30.2 & 81 & 69.8 \\
\hline $\begin{array}{l}\text { Quality and accessibility of the } \\
\text { handmade crafts and souvenirs }\end{array}$ & & & 29 & 25 & 87 & 75 \\
\hline Quality of products and services & & & & & 116 & 100 \\
\hline
\end{tabular}

Note: Impacts are assessed by survey participants and -1 indicates negatively affected, 0 is no impact and ldefines the positive impact.

It is maintained that the impacts of waste and pollution have affected the traditional customs, national arts and cultural

\section{CONCLUSIONS}

This study was conducted to assess the impact of tourism on the environment and socio-culture of KTTNNP.

In terms of the environmental impacts, 71.4 percent of the respondents said that the pollution has negative impacts, 52.7 percent soil erosion, 45.6 percent - water pollution and 29.2 percent referred to biodiversity depletion. Overcrowding of visitors during the summer season should be reduced to prevent the negative impacts and to develop sustainable tourism, while at the same time, ways and means must be identified to decrease the negative impacts.

In terms of socio-cultural impacts, $100 \%$ of the survey participants said that waste and pollution have a negative impact, $39.7 \%$ said that they harm the traditional customs, $45 \%$ national arts and cultural development, but development. Clearly, it has no impact on religion and leisure time. tourism has positive impact on the socioculture by developing the organization's foreign relations and ties, products, types and quality of services, protecting the natural and historical attractions and improving the skills of employees of the tourist industry. This means that local communities have positive attitudes towards developing tourism. Therefore, it is possible to increase community participation through the development of community-based tourism.

In the near future, it is essential to organize multilateral activities to reduce the negative environmental, socio-cultural impacts of tourism. For example, appropriate management of waste can be introduced to reduce waste.

To reduce the negative impacts on society, it is important to organize multilateral 
activities to help educate the local community and to provide them with information about tourism. Furthermore, it is possible to increase the efficiency of tourism in local areas by encouraging local citizens to learn more about tourism, extending the stay of tourists, and developing special interest tourism.

\section{REFERENCES}

1. MET. (2017). The management plan for tourism in Khorgo-Terkhiin Tsagaan Nuur National Park.

2. World Bank. (2011). Mongolian Tourism sector and Economic Impacts.

3. Eagles, P. M. (2002). Sustainable Tourism in Protected Areas.

4. MET, Administration of Khangai Mountain Range. (2016). The management plan for tourism in Khorgo-Terkhiin Tsagaan Nuur and Noyon Khangai National Park.

5. Bayasgalan. L, Baasannamjii. B. (2015). "The methodology issue for estimating the travelrecreational load" (on the example of Khorgo Terkhiin Tsagaan Nuur National Park).
6. World Commission on Protected Areas. (2002). Sustainable Tourism in Protected Areas-Guidelines for Planning and Management: Best Practice Protected Area Guideline Series No. 8.

7. Europarc Federation. (2015). Sustainable Tourism in Protected Areas-Good for parks, good for people.

8. DSE-German Foundation for International Development. (2002). The Ecotourism Training Manual for Protected Area Managers.

9. Gansukh. D, Erdenetuul. S, Navchaa. T. (2014). The methodology for estimating the impact of tourism on the environment, society and economy. 